\title{
Unit of Illuminance
}

National Cancer Institute

\section{Source}

National Cancer Institute. Unit of Illuminance. NCI Thesaurus. Code C69430.

A unit of measurement for intensity of the incident light defined as the total luminous flux incident on a surface per area unit. 